551.8

\author{
• цишин \\ ьвівський н ціон льний університет імені в н \\ вул. . орошенк , 41, м. ввів, 79000, кр їн
}

підст ві дет льного морфологічного, морфометричного н лізу тер с ністр, його к рп тських приток, н лізу розрізів тер с відтворено головні ет пи верхньопліоцен-нижньоплейстоценової історії розвитку долини ністр у р йоні лич, в но- $\mathrm{p}$ нківськ . роведено грунтовні геоморфологічні дослідження рівнів оєвої, р сної т уточнено деякі уже уст лені положення про їхню будову, поширення, ч с формув ння. леогеогр фічні події скорельов но зі ст діями ізотопно-кисневої шк ли, п леом гнітними репер ми, стр тигр фічними горизонт ми лесово-грунтової серії лицького ридністер'я.

лючові слов : рівень р сної, рівень оєвої, тер с , ізотопно-киснев ст дія, тектонічні підняття, ерозійне вріз ння, кумуляція лювію.

лицьке ридністер'я - р йон н дзвич йно цік вий, оскільки розміщений н стику двох великих, морфологічно відмінних між собою відтинків долини ністр - передк рп тського і подільського. олин річки тут поєднує одноч сно перші, ще сл бко виp жені риси дністерського к ньйону з крутими уривистими борт ми долини, прит м нними оділлю, і високопідняті широкі вирівняні межиріччя пр вих приток ністр , $\mathrm{x}$ р ктерних для ередк рп ття. огляду н це вв ж ємо, що $\mathrm{p}$ йон може бути ключем до розуміння 6 г тьох пит нь 3 історії розвитку, геоморфологічної будови долини ністр , ередк рп ття, оділля, пит ння геолого-геомофологічної вивченості лицького ридністер'я н був ють виняткової в жливості.

йскл днішими для геоморфологічних досліджень і п леогеогр фічних реконструкцій є верхньопліоценовий т еоплейстоценовий ет пи розвитку долини ністр , які з фіксов ні, відповідно, сьомою т шостою н дз пл вними тер с ми (рівень р сної і рівень оєвої) [6, 12]. ьом н дз пл вн тер с зберегл ся фр гмент рно, зокрем н привододільних ділянк $\mathrm{x}$ орон - ністерського межиріччя т у прилеглих до лицького ридністер'я р йон х - в околицях с. p сне (межиріччя імниці- истриці- олотвинської) т між ністром і лінією, проведеною вздовж н селених пунктів он стириськ - уч ч $[2,6,9]$. бсолютні відмітки поверхні тер си н межиріччі орони- ністр колив ються у меж х 320-330 м, що ст новить 115-125 м щодо русл ністр , цоколь сяг є 104-106 м н д руслом річки. ідносні перевищення поверхні тер си стосовно русл истриці сяг ють 107-113 м, цоколю - 97-102 м. с н копичення лювію тер си визн чений лише приблизно - верхній пліоцен, тобто пон д 1770 тис. років тому, бо до 64 ізотопно-кисневої ст дії ( ) [11].

(C) цишин ., 2010 
нші пит ння, як, н прикл д, поч ток процесу н копичення лювію тер си, які водотоки бр ли уч сть у його н копиченні, н прями їхніх течій, реконструкція п нівних у ч с формув ння тер си фізико-геогр фічних умов тощо досі ост точно не вирішені.

ступний, не менш дискусійний ет п у формув нні рельєфу, н копиченні континент льних відкл дів території лицького ридністер'я, пов'яз ний з розвитком шостої н дз пл вної тер си (рівня оєвої). я тер с зберегл сь ліпше, у тому числі в лицькому ридністер'ї, що сприяє проведенню грунтовніших геоморфологічних досліджень т уточненню деяких уже уст лених положень про їі будову, ч с формув ння тощо. дже очевидно, що схеми розвитку долини, у яких інтерв л від м йже 1,8 млн років тому до приблизно 860 тис. років тому (трив лість еоплейстоцену - 64-22 [11]), тобто м йже 1 млн років відведено лише н формув ння однієї (шостої) н дз пл вної тер си (рівня оєвої), вигляд ють дещо спрощеними.

оч тковим для уточнень історії розвитку долини ністр протягом еоплейстоцену в меж $\mathrm{x}$ лицького ридністер'я треб прийняти розріз тер си у гвізді (рис. 1, 2), де $€$ чіткий репер - н д лювієм в одному з трьох викопних грунтів, які стр тигр фічно відповід ють викопному грунту типу м ртонош, визн чен меж п леом гнітних епох туям - рюнес [19].

тже, ч с н копичення лювію цієї тер си прип в н еоплейстоцен, тобто н ч с формув ння шостої н дз пл вної тер си ністр (рівня оєвої) [6]. Дн к якщо це шост н дз пл вн тер с, то потрібно перегляд ти номенкл туру тер с, розт шов них гіпсометрично вище, які формують вододільні т привододільні ділянки межиріччя истриці- олотвинської- імниці. дже, відповідно до з г льноприйнятої схеми геоморфологічної будови долини ністр, шост, сьом н дз пл вні тер си - це т к зв ні н дк ньйонні, які розт шов ні с ме н межиріччях пр вих приток ністр, не у борт х їхніх долин $[1,6,7,15]$. обто є явн незбіжність між, з одного боку, морфологічними, морфометричними п р метр ми тер си - іiі розт шув нням у борті глибоко вріз ної долини річки, відносної висоти тер си стосовно русл истриці- олотвинської, з зіншого, - будови розрізу с мої тер си, зокрем , її лесово-грунтового покриву i, що н йбільш в гомо, п леом гнітних д них.

зн чимо, що ф кт невідповідності номенкл тур тер с, розроблених н концептульно різних з с д х - морфологічній т історико-геологічній, є досить поширеним явищем під ч с досліджень у долині ністр .

побудов них профілів, особливо з кл деного впоперек межиріччю истриці- олотвинської- імниці (див. рис. 2-4), виплив є, що поверхня оєвої н межиріччі імниці- истриці- олотвинської у меж х лицького ридністер'я об'єднує декільк гіпсометрично відмінних між собою рівнів (тер с) (див. рис. 1). еред них гіпсометрично н йвищ - перш - тер с зберегл ся, орієнтовно, у трикутнику еніїв- ибне- йд н, де вон формує вододіл між уквицею і истрицею- олотвинською (див. рис. 1). околицях еніїв поверхня тер си витрим н н рівні 370 м, зрост є до 380 м у міру просув ння н південний з хід межиріччя. ідносн висот поверхні тер си стосовно русл истриці сяг є 147 м, щодо русл истриці- олотвинської - 124 м. исот цоколю сяг є, відповідно, 142 і 105 м. люві льн товщ тер си є водоносним горизонтом, яким живляться витоки рік ілков т, влівк .

руг, гіпсометрично нижч тер с розвинен н межиріччях уквиці- влівки т

влівки- истриці- олотвинської. ї можн відстежити у т ких меж х: південн околиця с. ікторів, с. еніїв і до с. ибне (див. рис. 1). ділянці ікторів- еніїв теp c формує вододіл рік уквиці т влівки. ї поверхня сяг є 345-370 м, у відносній 
шк лі висот це ст новить 122-147 м стосовно русл истриці т 90-115 м - истриціолотвинської. исот цоколю сяг є, відповідно, 118-122 т 90-95 м.

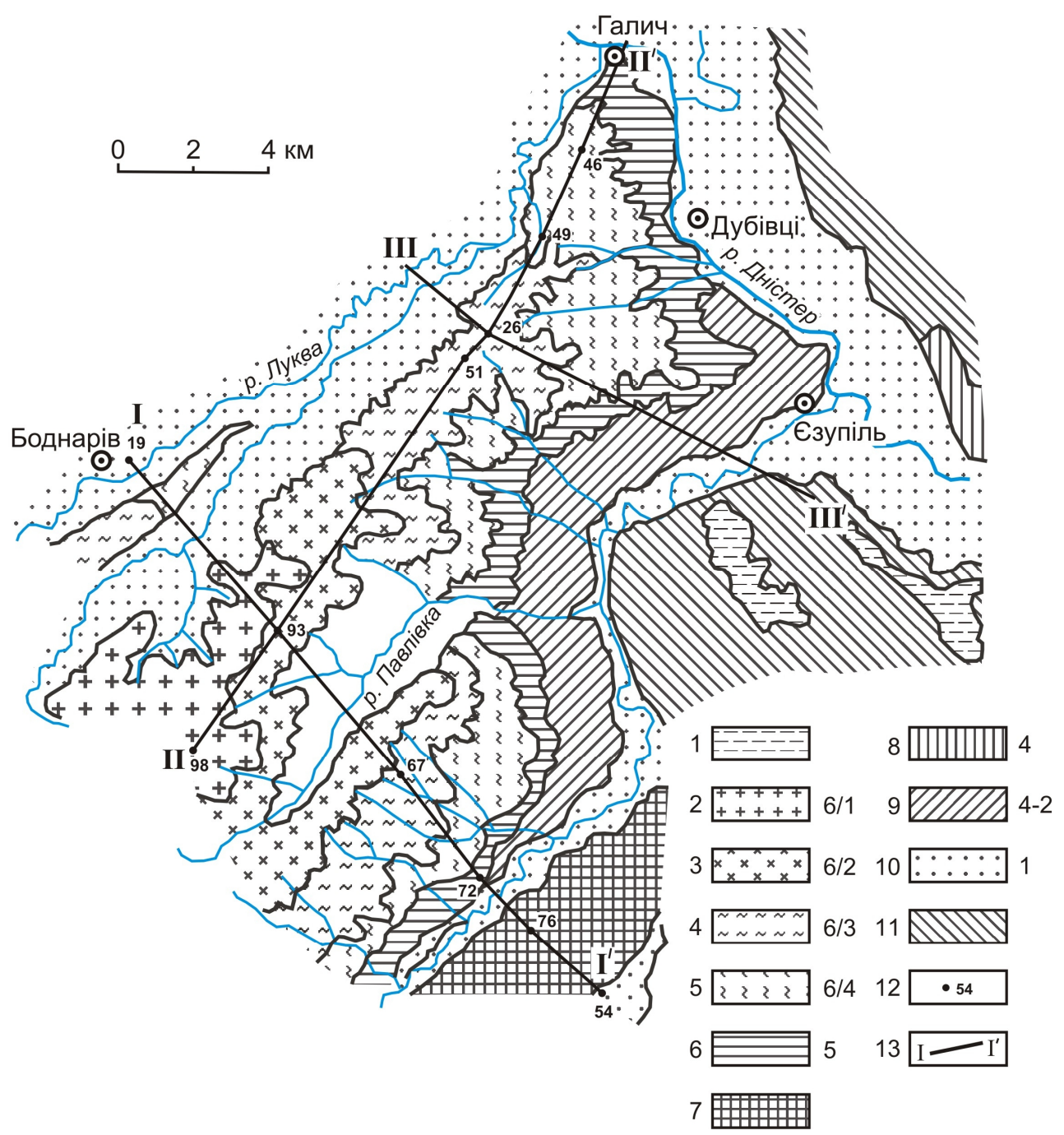

ис. 1. ічкові долини з комплексом тер с: 1 - верхньопліоценов сьом н дз пл внв тер с (рівень р сної); 2 - перший рівень (тер с -?) еоплейстоценової поверхні оєвої; 3 - другий рівень (тер с -?) еоплейстоценової поверхні оєвої; 4 - третій рівень (тер с -?) еоплейстоценової поверхні оєвої; 5 - четвертий рівень (тер с -?) еоплейстоценової поверхні оєвої; 6 - нижньоплейстоценов п'ят н дз пл вн тер с ; 7-нерозчленов ні нижньо-верхньоплейстоценові п'ят друг н дз пл вні тер си; 8-середньоплейстоценов четверт н дз пл вн тер с ; 9-нерозчленов ні середньо-верхньоплейстоценові четверт -друг н дз пл вні тер си; 10 - голоценов перш тер с (висок з пл в ), серія різновисотних 3 пл вних рівнів; 11 -ерозійно-денуд ційні поверхні. нше: 12 - свердловини т їхні номери; 13 -лінія геолого-геоморфологічного профілю. 


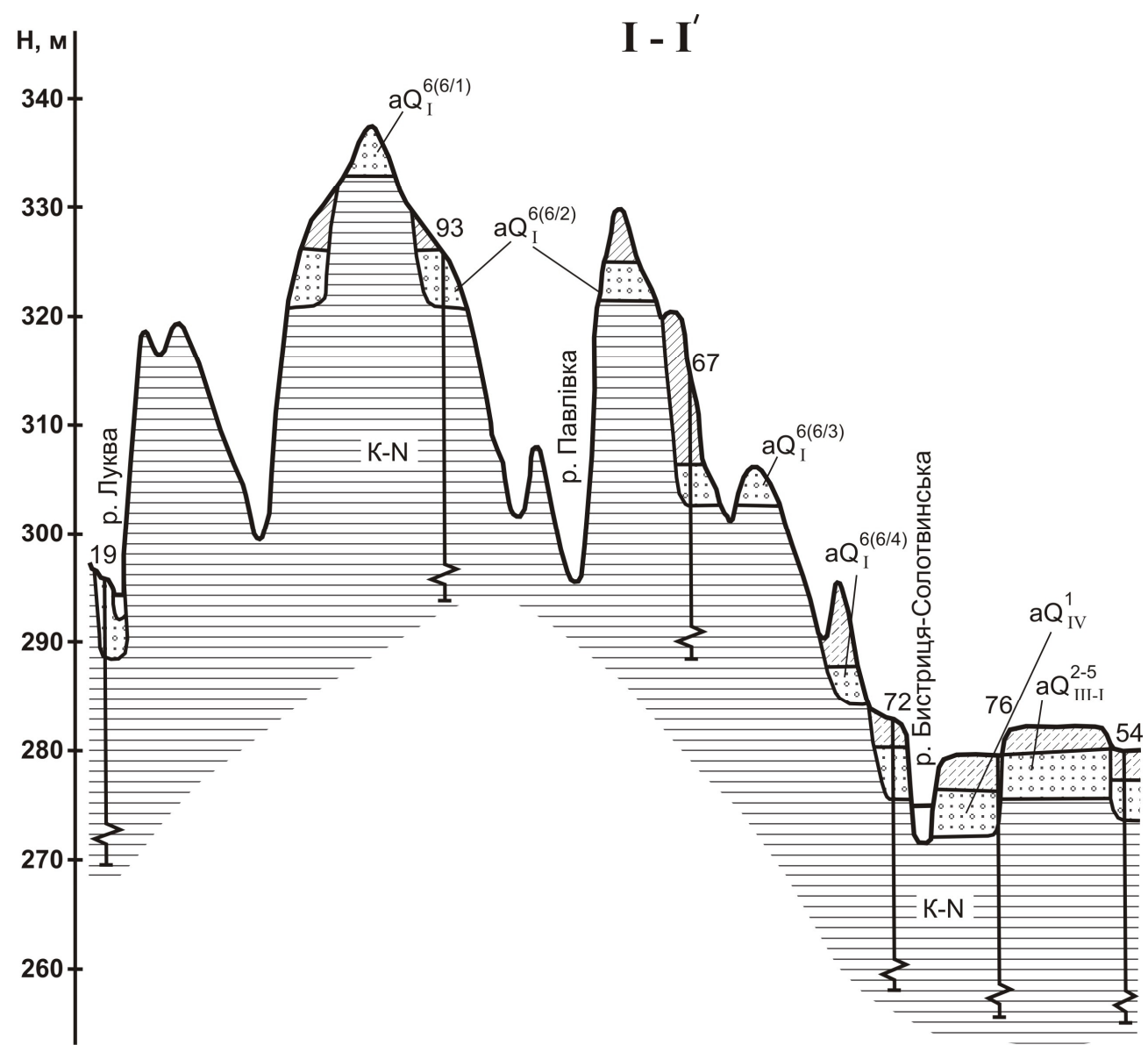

ис. 2. хем тичний геолого-геоморфологічний розріз межиріччя імниці- истриці- олотвинської по лінії - '.

ітологічні: 1 - супіски; 2 - суглинки; 3 - піски; 4 - гр війно-г лечниковий м тері л; 5 - мергелі, глини, гіпси, в пняки (корінні відкл ди). енетичні: - люві льні; $v d$ - еолово-делюві льні. тр тигр фічні: $Q_{\mathrm{IV}}{ }^{1}$ - голоценові першої тер си (високої з пл ви), 3 пл вних рівнів; $Q_{\mathrm{III-}}^{2-5}-$ нерозчленов ні верхньо-, нижньоплейстоценові другої-п'ятої н дз пл вних тер с; $Q_{\mathrm{I}}^{5}-$ нижньоплейстоценові п'ятої н дз пл вної тер си; $Q_{\text {I-IV }}{ }^{2}$ - нижньоплейстоцен-голоценові п'ятої н дз пл вної тер си; $Q_{\mathrm{I}}^{6(6 / 4)}$ - еоплейстоцен-нижньоплейстоценові четвертого рівня (тер си-?) рівня оєвої; $\mathrm{Q}_{\mathrm{I}}^{6(6 / 3)}-$ еоплейстоценові третього рівня (тер си-?) рівня оєвої; $Q_{\mathrm{I}}^{6(6 / 2)}-$ еоплейстоценові другого рівня (тер си-?) рівня оєвої; $Q_{\mathrm{I}}^{6(6 / 1)}$ - еоплейстоценові першого рівня (тер си-?) рівня оєвої; $N_{2}{ }^{7}$ - верхньопліоценові сьомої тер си; $-N$ - корінні (крейдові, неогенові). нше: 76 - номер свердловини.

ступн тер с з переліку тих, які сьогодні об'єдн ні у рівень оєвої, розвинен н межиріччях укви- ністр т укви- истриці н ділянці від с. рилос до лінії, проведеної від с. язів до південної околиці с. ікторів (див. рис. 1). цьому трикутнику тер с формує вододільні ділянки межиріч укви- ністр т укви- истриці. ї поверхня пл вно піднім ється з півночі н південь від 305 до 325 м і більше. ідносн ви- 
сот поверхні тер си стосовно русл ністр витрим н н рівні 105-125 м, цоколю 92-95 м. південно-з хідній околиці с. язів тер с “втр ч є” вододільні позиції, переміщуючись н східний м кросхил межиріччя укви- истриці, де формує тер сову сходинку у лівому борті долини истриці т истриці- олотвинської. ідносн висот поверхні тер си стосовно русл истриці колив ється у меж х 94-109 м, цоколю - до 86 м. долині истриці- олотвинської тер с розвинен у іiі лівому борті, н північно3 хідних околицях сіл гвіздя, циків. ідносн висот поверхні тер си стосовно русл истриці- олотвинської сяг є 45-80 м, цоколю - до 45 м. ме розріз цієї тер си сьогодні опр цьов ний у р йоні с. гвіздя.

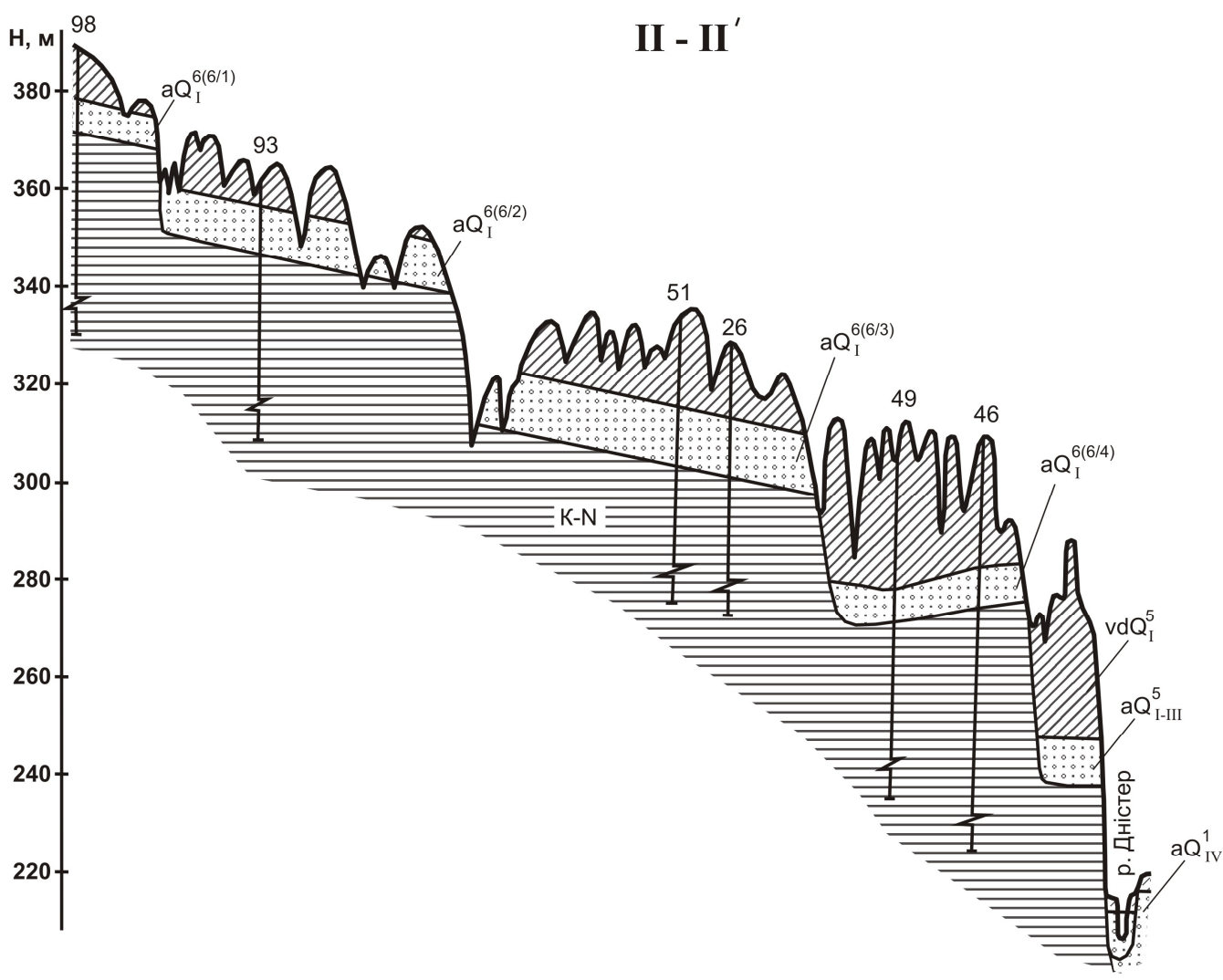

ис. 3. хем тичний геолого-геоморфологічний розріз межиріччя імниці- истриці- олотвинської по лінії - '.

озн чення ті ж, що йн рис. 2.

іпсометрично н йнижч серед тер с рівня оєвої четверт тер с розвинут у р йоні лич - рилос, де вон формує вододільні ділянки межиріччя укви- ністр (див. рис. 1). оверхня тер си витрим н н рівні 290-300 м, що ст новить 85-95 м н д руслом ністр , висот цоколю-70-75 м. івденніше с. рилос тер с “сповз $є$ ” з вододільних ділянок межиріччя н східний м кросхил т простяг ється до північної, пів- 
нічно-з хідної околиць с. ілець. івденніше с. ілець тер с “виходить” у долину истриці, де розвинен н з хідній околиці с. язів т північній околиці с. влівк . оверхня тер си витрим н н рівні 57-77 м стосовно русл истриці, цоколь досяг є 55 м пон д руслом річки. івденніше с. влівк тер су можн відстежити вже у долині истриці- олотвинської, зокрем , н східній околиці с. гринів, з хідних околицях сіл гвіздя, циків. ідносні висоти її поверхні стосовно русл цієї річки знижуються до 30-50 м, цоколю - до 23 м.

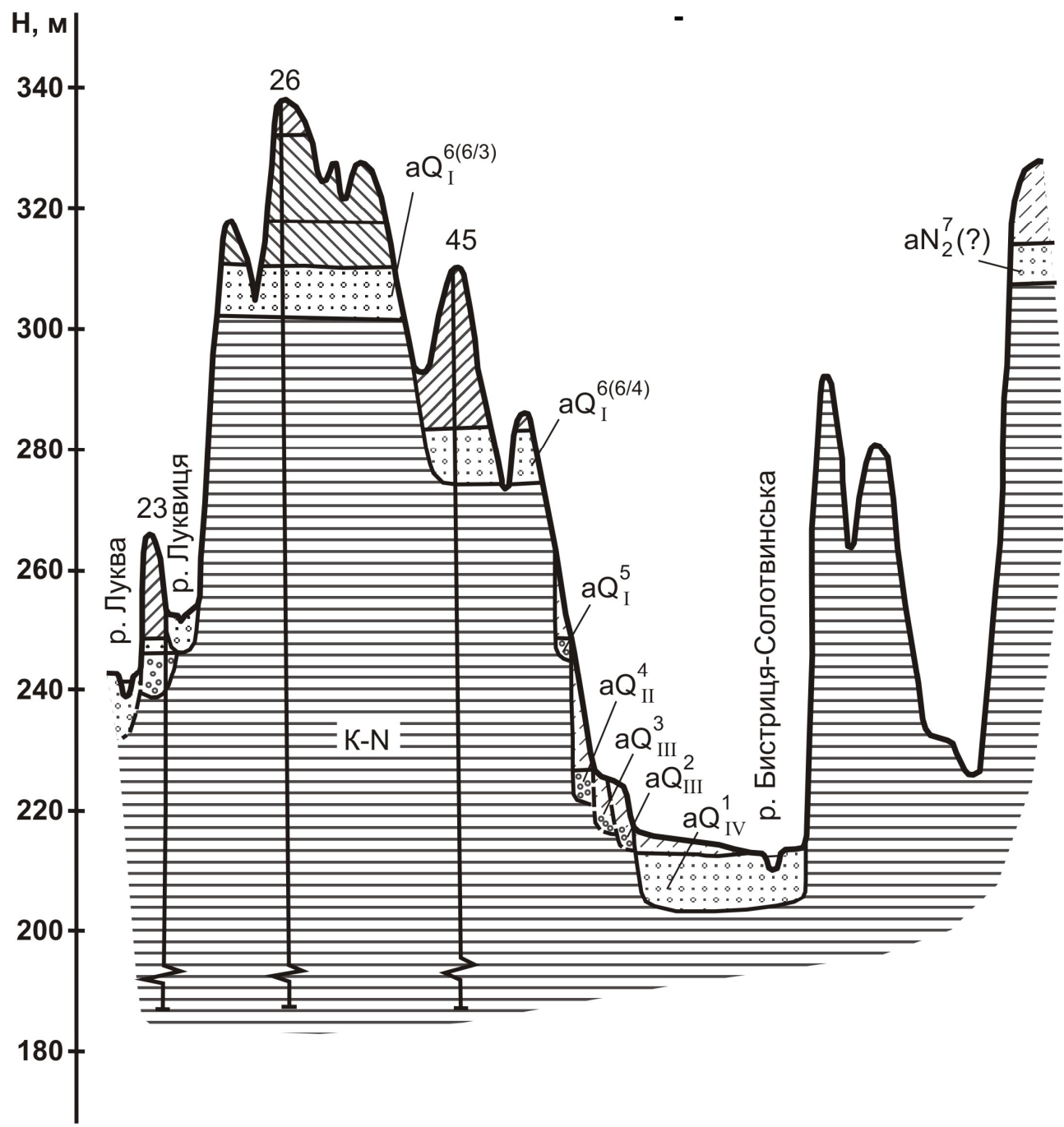

ис. 4. хем тичний геолого-геоморфологічний розріз межиріччя імниці- истриці- орони по лінії _ ,

озн чення ті же, що йн рис. 2. 
нший фр гмент цієї тер си зберігся безпосередньо у долині ністр н південній околиці с. овге, де формує брівку глибоко вріз ної к ньйоноподібної долини ріки. орфометричні х р ктеристики тер си н дзвич йно близькі до тих, які прит м нні теp сі, розт шов ній у р йоні лич - рилос : відносн висот поверхні н д руслом ністр колив ється у меж х 85-95 м, висот цоколю - 75-80 м.

огічно пост вити з пит ння - як інтерпретув ти опис ні рівні? к різновікові утворення, тобто тер си, які сьогодні об'єдн ні у т к зв ний рівень оєвої? бо як гіпсометрично відмінні блоки поверхні оєвої, що сформув лися вн слідок розвитку трив лих різно млітудних, можливо, й різнон прямлених тектонічних рухів, які й розбили н окремі блоки колись монолітну еоплейстоценову шосту тер су (рівень оєвої)? н логічні пит ння виникли під ч с дет льного дослідження рівня оєвої у долині тривігору ( івнічно- хідне ередк рп ття) [19].

пропонов н схем гіпсометричних рівнів поверхні оєвої з чіп є т кож описув ний н межиріччі орони- ністр рівень р сної $[6,9]$. иникли підст ви переглянути 3 йм ні зг д ним рівнем геоморфологічну, вікові позиції і, н голошуємо, спир ючись винятково н морфометричні критерії, розгляд ти його як один з рівнів поверхні оєвої (рис. 4).

дн к відшук ти для нього місце у 6 г торівневій системі поверхні оєвої сьогодні вельми скл дно (т бл. 1).

блиця 1

орфометричні х р ктеристики еоплейстоцен-верхньопліоценових тер с ністр

\begin{tabular}{|c|c|c|c|c|}
\hline \multicolumn{2}{c|}{ у } \\
\hline \multirow{2}{*}{ івень } & $\begin{array}{c}\text { бсолютн } \\
\text { відмітк } \\
\text { поверхні, м }\end{array}$ & ністр & $\begin{array}{c}\text { иднтриці- } \\
\text { олотвинської }\end{array}$ & истриці \\
\cline { 3 - 5 } & $290-300$ & $70-75$ & $23-26$ & $52-55$ \\
\hline $\begin{array}{c}\text { етвертий рівень } \\
\text { поверхні оєвої }\end{array}$ & $305-325$ & $92-95$ & $40-45$ & $81-86$ \\
\hline $\begin{array}{c}\text { ретій рівень } \\
\text { поверхні оєвої }\end{array}$ & $345-360$ & $135-140$ & $90-95$ & $118-122$ \\
\hline $\begin{array}{c}\text { ругий рівень } \\
\text { поверхні оєвої }\end{array}$ & $370-380$ & $162-165$ & $100-105$ & $143-145$ \\
\hline $\begin{array}{c}\text { ерший рівень } \\
\text { поверхні оєвої }\end{array}$ & $320-330$ & $104-106$ & $81-84$ & $95-98$ \\
\hline івень р сної & & & & \\
\hline
\end{tabular}

орфометрично н йближчий до нього третій рівень поверхні оєвої. ерівними для н с у цьому вип дку є, перш $з$ все, відносні відмітки цоколів описув них рівнів стосовно русл р. истриці.

ти обгрунтов ні й вичерпні відповіді н ці т б г то інших 3 пит нь сьогодні н дзвич йно скл дно. рипустимо, це “с мостійні” різновікові тер си. т кому вип дку лицьке ридністер'я буде р йоном, де зберегл ся пр ктично повн ( бо й уз г лі повн ) номенкл тур тер с ністр, п леогеогр фічні події, ймовірно, могли б розгорт тися т к:

$>$ у верхньому пліоцені (до 64), ймовірно, лише н передк рп тській ділянці долини ністр (р йон с. р сне) формув л ся сьом н дз пл вн тер с (рівень р сної) (т бл. 2). люві льний м тері л тер си н копичув ли водотоки, які вільно переміщув лись по території ередк рп ття, розт шов ній поблизу рп т, не досяг ючи оділля (суч сного межиріччя орони- ністр ); 
після н копичення лювію сьомої н дз пл вної тер си пр - ністер розділив іiі, формуючи уступ до гіпсометрично н йвищого рівня (тер си-?) поверхні оєвої (див. т бл. 2). 'ясув ти достовірно й обгрунтов но, коли відбув лось розчленув ння сьомої тер си (рівня р сної) - у верхньому пліоцені, чи вже в еоплейстоцені, сьогодні скл дно. либин вріз ння, тобто різниця висот між рівнем $\mathrm{p}$ сної і оєвої, у $\mathrm{p}$ йоні c. p сне, сяг є 40 м. и в рто в т кому вип дку говорити про перші морфологічні контури долини пр - ністр ? е т кож н дзвич йно скл дне 3 пит ння, оскільки в ередк рп тті збереглися лише окремі невеликі, ізольов ні між собою ділянки сьомої тер си. они не д ють підст в припуск ти бо спростовув ти ідею широкого розвитку сьомої тер си, як $б$ і могл формув ти в еоплейстоцені, чи хоч $б$ його першій половині, борти долини ністр ;

$>$ вироблення ерозійного уступу до н ступного гіпсометрично нижчого другого рівня (тер си-?) поверхні оєвої відбув лось, імовірно, під ч с розвитку висхідних, територі льно диференційов них, тектонічних рухів. ксимум цих піднять був з хідніше, південно-з хідніше території досліджень. ро це свідч ть: розвиток гіпсометрично нижчого другого рівня поверхні оєвої північно-східніше ділянки межиріччя, предст вленої попереднім, гіпсометрично н йвищим рівнем поверхні оєвої (див. рис. 1), т кож ухил люві льного горизонту н йвищого рівня поверхні оєвої н північний схід (див. рис. 3). н слідок цих рухів русло ністр змістилось н північний схід, ле все ще не досяг ло оділля (суч сного межиріччя орони- ністр ).

ей рівень, можливо, фіксує ще одну в жливу п леогеогр фічну подію - у ч с їі формув ння к рп тські притоки ністр ( истриця- олотвинськ, імниця) н були суч сного н пряму течії: з південного з ходу н північний схід. ідносн висот межиріччя пр вих приток ністр могл досягнути 10-25 м.

сі події - н копичення лювію гіпсометрично н йвищого рівня поверхні оєвої, пї розчленув ння т н копичення лювію н ступного гіпсометрично нижчого рівня поверхні оєвої, відбув лись, н н ш погляд, протягом широкінського інтергляці лу (див. т бл. 2). е у проміжку від 1,2 до приблизно 1 млн років тому ( 38-28). ожливо, н копичення лювію гіпсометрично нижчої тер си з вершилось у першій половині при зовського гляці лу (?), який охоплює 27-22 [11]. цьому вип дку з вершення процесу н копичення лювію другої тер си, з переліку тер с рівня оєвої, прип де н

25-24, тобто до 955 тис. років тому;

$>$ н 3 вершенні при зовського гляці лу - поч тку м ртоноського інтергляці лу, тобто між 24-25 і 21, бо від 955 до 865 тис. років тому, відбулося розчленув ння другого з переліку рівня (тер си-?) поверхні оєвої т вироблення ерозійного уступу до н ступного гіпсометрично нижчого третього рівня (тер си-?) поверхні оєвої (див. т бл. 2). різ ння ністр відбув лося вн слідок розвитку висхідних i, знову ж т ки, територі льно диференційов них тектонічних рухів з епіцентром, розт шов ним н 3 хід-південний з хід від р йону досліджень. ро це свідч ть: розвиток описув ного рівня північно східніше попереднього, гіпсометрично вищого рівня поверхні оєвої (див. рис. 1); ухил люві льного горизонту попереднього - другого - рівня поверхні оєвої н північний схід (див. рис. 3). обто п р лельно з вріз нням відбулось н ступне зміщення русл річки н схід-північний схід. н слідок цього зміщення русло ністр досягло орон - ністерського межиріччя ( оділля), де сьогодні описують сьому н дз пл вну тер су ністр (рівень р сної) [9]. либин долин к рп тських приток ністр у лицькому ридністер'ї в цей ч с сягл вже 50-60 м, с мі водотоки ост точно н були н пряму д - н ; 
> н поч ток м ртоноського інтергляці лу, пон д 865 тис. років тому, прип ло н копичення лювію третього рівня (тер си-?) поверхні оєвої і, можливо, м тері лу н межиріччі орони- ністр, який описують сьогодні як лювій сьомої н дз пл вної тер си ністр (можливо, протягом лише 21 ) (див. т бл. 2). годом лювій перекрили викопні грунти (у розрізі гвіздя збереглися три викопні грунти) типу м ртонош - від 806 до 712 тис. років тому ( 20-17);

$>$ протягом другої половини м ртоноського інтергляці лу відбулося розчленув ння третього рівня (тер си-?) поверхні оєвої, вироблення ерозійного уступу до н ступного гіпсометрично н йнижчого четвертого рівня (тер си-?) поверхні оєвої т н копичення лювію цієї тер си (див. т бл. 2). вич йно, що як сь ч стин цього інтерв лу водоток ми бул 3 тр чен н вироблення ерозійного уступу, можливо, між 806 i 760 тис. років тому ( 20-18), решт - н кумуляцію лювію н йнижчої тер си рівня оєвої, інтерв л від 712 до 659 тис. років тому ( 17). різ ння ністр т кож було зумовлене розвитком висхідних, територі льно диференційов них тектонічних рухів 3 м ксимумом піднять 3 хідніше-південно-з хідніше території досліджень. они спричинили одноч сне вріз ння т, цього р зу, ост нне протягом еоплейстоцену зміщення русл ністр н схід-північний схід. е припущення підтверджене н йбільш східним розт шув нням описув ного рівня з усіх рівнів поверхні оєвої (див. рис. 1) т ухилом люві льного горизонту третього рівня поверхні оєвої н північний схід (див. рис. 3);

$>$ отже, н 3 вершення м ртоноського інтергляці лу - поч ток сульського гляці лу, рубіж у 659 тис. років тому ( 17-16) прип ло н копичення лювію гіпсометрично н йнижчого четвертого, рівня (тер си-?) поверхні оєвої (див. т бл. 2). либин долин к рп тських приток ністр - імниці, истриці- олотвинської у меж х лицького ридністер'я у цей ч с досягл 80-100 м. либин долини ністр н подільській ч стині лицького ридністер'я ст новил 25-35 м;

$>$ протягом другої половини сульського гляці лу, тобто пон д 621 тис. років тому ( 16), ун слідок розвитку висхідних тектонічних рухів відбулося вріз ння ністр у гіпсометрично н йнижчий рівень (тер су-?) поверхні оєвої, вироблення ерозійного уступу до п'ятої н дз пл вної тер си (див. т бл. 2). скільки люві льний горизонт ост ннього гіпсометрично н йнижчого рівня поверхні оєвої з ляг є пр ктично горизонт льно (див. рис. 3), то тектонічні підняття, очевидно, були більш-менш територі льно рівномірними, без чітких диференці цій мплітуд.

тже, із з пропонов ної вище схеми історії розвитку долини ністр у лицькому ридністер'ї протягом еоплейстоцену виплив $\epsilon$, що, по-перше, поверхня оєвої не $\epsilon$ монолітною поверхнею (тер сою), це об'єдн ння декількох гіпсометрично близьких між собою тер с; по-друге, формув ння цих тер с (рівня оєвої) прип ло н еоплейстоцен-нижньоплейстоценовий ч с; по-третє, описув н н межиріччі орони- ністр тер с як сьом н дз пл вн (рівень р сної), можливо, н лежить до рівня оєвої (третій рівень поверхні оєвої); по-четверте, вільне блук ння (ме ндрув ння) ністр по ередк рп тті ( лицькому ридністер'ї) відбув лось протягом першої ч стини еоплейстоцену, у його другій ч стині й н поч тK х нижнього плейстоцену долин ністр вже могл н бути перших більш-менш чітких морфологічних обрисів, можливо, вже сформув лися долини його к рп тських приток, між ними виникли вододіли.

зн чимо, що д лі н 3 хід по межиріччі истриці- олотвинської- імниці 3 меж ми лицького ридністер'я між рівнем р сної (г. p сн ) і гіпсометрично н йвищим рівнем поверхні оєвої існують ще декільк гіпсометрично відмінних між собою 
мовірн послідовність п леогеогр фічних подій верхньопліоценнижньоплейстоценового ет пу розвитку території лицького ридністер'я

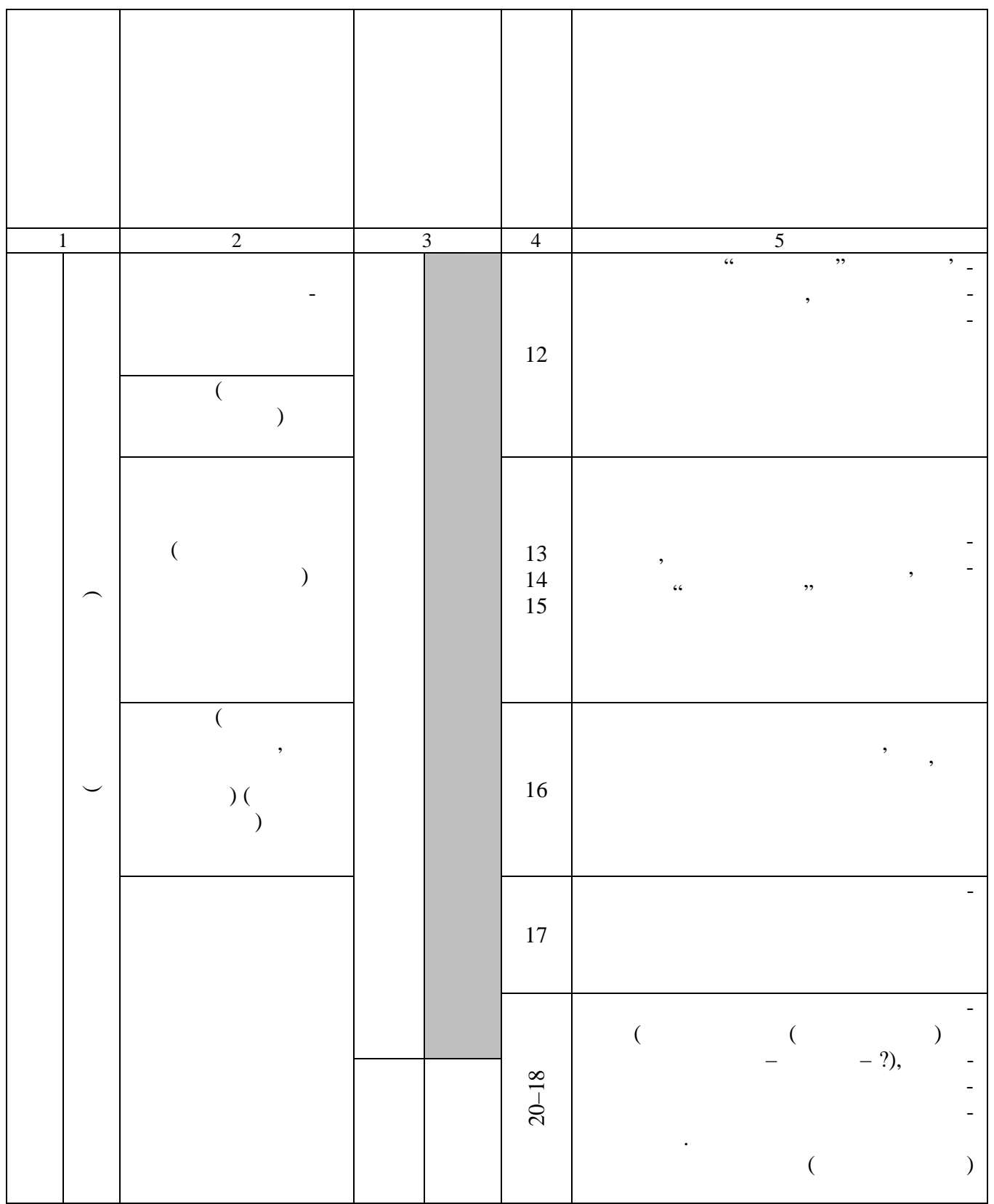


кінчення т бл. 2

\begin{tabular}{|c|c|c|c|c|}
\hline 1 & 2 & 3 & 4 & 5 \\
\hline & & & 21 & $\begin{array}{l}\text { копичення лювію третьої тер си рів- } \\
\text { ня оєвої т тер си н межиріччі орони- } \\
\text { ністр, яку описують як сьому н д- } \\
3 \text { пл вну (рівень р сної) }\end{array}$ \\
\hline & ри зовський лес & & $\begin{array}{l}\widehat{N} \\
\text { ปे }\end{array}$ & $\begin{array}{l}\text { вершення процесу можливого н ко- } \\
\text { пичення лювію другої тер си рівня } \\
\text { оєвої. прикінці при зовського гля- } \\
\text { ці лу-поч тку м ртоноського інтергля- } \\
\text { ці лу розчленув ння другої з переліку } \\
\text { рівня оєвої тер си т вироблення ус- } \\
\text { тупу до н ступної, гіпсометрично ниж- } \\
\text { чої, третьої тер си цього рівня }\end{array}$ \\
\hline & $\begin{array}{r}\text { ирокінський } \\
\text { педокомплекс }\end{array}$ & 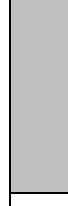 & $\begin{array}{c}\infty \\
\substack{\infty \\
\sim}\end{array}$ & $\begin{array}{l}\text { копичення лювію гіпсометрично н й- } \\
\text { вищої тер си рівня оєвої, її розчлену- } \\
\text { в ння т н копичення лювію н ступ- } \\
\text { ної гіпсометрично нижчої тер си рівня } \\
\text { оєвої }\end{array}$ \\
\hline & льїчівський лес & & $\stackrel{n}{y}$ & ? \\
\hline & $\begin{array}{c}\text { риж нівський } \\
\text { педокомплекс }\end{array}$ & & $\begin{array}{l}\text { ro } \\
1 \\
y\end{array}$ & $?$ \\
\hline & $\begin{array}{c}\text { лювій } \\
\text { сьомої н дз пл вної } \\
\text { тер си (рівня } \\
\text { р сної) }\end{array}$ & 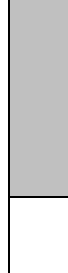 & $\begin{array}{l}\text { to } \\
1 . \\
\text { i. }\end{array}$ & $\begin{array}{l}\text { кумуляція лювію сьомої н дз пл в- } \\
\text { ної тер си (рівень р сної) у р йоні } \\
\text { с. р сне, імовірне розчленув ння цієї } \\
\text { тер си т вироблення ерозійного усту- } \\
\text { пу до гіпсометрично н йвищої тер си } \\
\text { рівня оєвої }\end{array}$ \\
\hline
\end{tabular}

блоків, які можуть бути не виявленими н р зі л нк ми верхньопліоцен-еоплейстоценової історії розвитку долини ністр , ередк рп ття.

одо іншого тлум чення опис них вище рівнів - як фр гментів колись єдиного рівня оєвої, то це припущення т кож м є в гомі підст ви н існув ння. окрем , потрібно вр ховув ти т ке: 
по-перше, це розт шув ння зовсім поряд з розрізом гвіздя в но- р нківської улоговини, як , н н ш погляд, почин ючи з нижнього плейстоцену (з верш льної ч стини еоплейстоцену-?), формув л ся в режимі тектонічних опуск нь;

$>$ по-друге, це концентр ція н межиріччі истриці- олотвинської- імниці м ксим льних пр ктично для всього ередк рп ття бсолютних відміток і відносних перевищень, що могли сформув тись лише вн слідок розвитку інтенсивних висхідних тектонічних рухів. ксимум цих піднять розт шов ний з хідніше-північно-з хідніше території досліджень у р йоні вершин $\mathrm{p}$ сн, елений $\mathrm{p}$, які н леж ть до фр гментів сьомої н дз пл вної тер си (рівня р сної). ричому у “поведінці” підошви четвертинних відкл дів межиріччя м є яскр во вир жений східцеподібний, блоковий х р ктер (див. рис. 2-4).

ому тер су у с. гвіздя можн т кож розгляд ти як один з опущених блоків рівня оєвої, тер си, які формують поверхню межиріччя истриці- олотвинської- імниці, - як фр гменти рівня оєвої, що не були з хоплені н стільки інтенсивними низхідними тектонічними рух ми бо, н вп ки, були з хоплені висхідними тектонічними рух ми (див. рис. 2). т кому вип дку п леогеогр фічні події пліоцен-нижньоплейстоценового ет пу розвитку лицького ридністер'я розгорт лися б т к, як відобр жено в т бл. 3.

ожливо, що у цій площині, тобто розвиткові різно мплітудних бо й різновекторних тектонічних рухів, т кож треб шук ти відповіді н проблеми походження, історії розвитку і будови в но- $\mathrm{p}$ нківської улоговини. гідно з д ними побудов них геологогеоморфологічних профілів, н окремих ділянк х, зокрем , у р йоні в но- $\mathrm{p}$ нківськ , поверхню улоговини утворюють нижньо-, верхньплейстоценові п'ят -друг н дз пл вні тер си (див. рис. 2). ому можн припустити, що улоговин формув л ся в умов х трив лих тектонічних опуск нь цього фр гмент ередк рп ття, яке могло розпоч тись у нижньому плейстоцені (з верш льній ч стині еоплейстоцену-?) т трив ло до верхнього плейстоцену.

ретій п леогеогр фічний ет п розвитку території лицького ридністер'я корелює з розчленув нням рівня оєвії (його ост нньої гіпсометрично н йнижчої тер си), формув нням ерозійного уступу до п'ятої н дз пл вної тер си і н копиченням лювільної товщі цієї тер си. різ ністр , його приток у поверхню рівня оєвої пов'язують, як з зн чено вище, з розвитком більш-менш рівномірних з мплітудою висхідних тектонічних рухів, які охопили ередк рп ття, оділля. к н слідок, сформув лися перші контури ністерського к ньйону глибиною до 35 м. кщо розгляд ти рівень оєвої в його суч сних меж х - єдиний рівень, що формув вся протягом еоплейстоцену, то розгорт ння зг д них вище геоморфологічних подій охоплює м ртоноський, сульський, лубненський і ч стину тілігульського ч су. е приблизно 806-427 тис. років тому, бо протягом 21-12 (див. т бл. 2, 3). чевидно, що ч стин цього ет пу прип д л н процес формув ння ерозійного уступу до п’ятої н дз пл вної тер си (врі3 ння ністр з приток ми у поверхню оєвої), можливо, між 806-568 (?), бо 474 (?) тис. років тому, тобто протягом 21-15 (?) чи 13 (?). ншу ч стину ет пу х р ктеризує процес н копичення лювію п'ятої н дз пл вної тер си у проміжку між 621474 тис. років тому, бо протягом 15 (13-?)-12. ізико-геогр фічні умови цього ет пу вкр й мінливі - від теплих інтергляці льних до дуже холодних перигляці льних. ричому зміни м ли яскр во вир жений циклічний х р ктер: холодний при зовський ч с (лесовий горизонт у розрізі гвіздя), теплий м ртоноський ч с (викопний грунт типу гвіздя), знову холодний сульський ч с (лесовий горизонт у розрізі гвіздя), теп- 
блиця 3

мовірн послідовність п леогеогр фічних подій верхньопліоцен-

нижньоплейстоценового ет пу розвитку території лицького ридністер'я

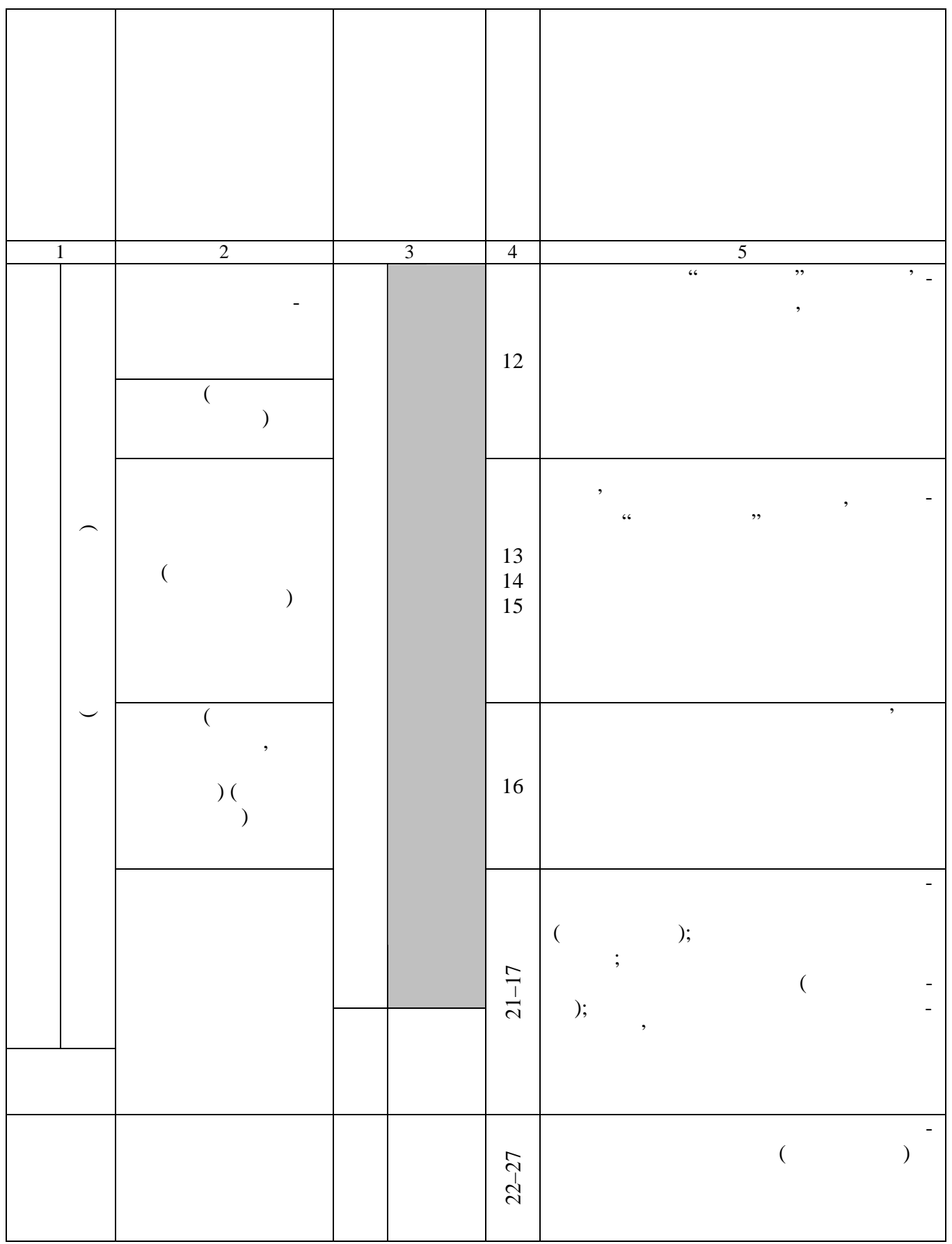




\begin{tabular}{|c|c|c|c|c|}
\hline 1 & 2 & 3 & 4 & 5 \\
\hline & $\begin{array}{r}\text { ирокінський } \\
\text { педокомплекс }\end{array}$ & $\begin{aligned} \mathrm{p}- \\
\text { мільйо }\end{aligned}$ & $\begin{array}{l}\infty \\
\substack{\infty \\
\sim}\end{array}$ & $\begin{array}{l}\text { ироблення ерозійного уступу до шос- } \\
\text { тої н дз пл вної тер си (рівня оєвої) }\end{array}$ \\
\hline & льїчівський лес & & $\begin{array}{l}n \\
\text { † } \\
\text { ma }\end{array}$ & $\begin{array}{l}\text { ироблення ерозійного уступу до шос- } \\
\text { тої н дз пл вної тер си (рівня оєвої) }\end{array}$ \\
\hline & $\begin{array}{l}\text { риж нівський } \\
\text { педокомплекс }\end{array}$ & & $\begin{array}{l}\text { Oొ } \\
1 \\
\text { do }\end{array}$ & $\begin{array}{l}\text { ироблення ерозійного уступу до шос- } \\
\text { тої н дз пл вної тер си (рівня оєвої) }\end{array}$ \\
\hline & $\begin{array}{c}\text { лювій } \\
\text { сьомої н дз пл вної } \\
\text { тер си (рівня } \\
\text { р сної) }\end{array}$ & $\begin{array}{l}\text { лду- } \\
\text { вей }\end{array}$ & 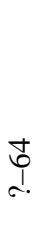 & $\begin{array}{l}\text { кумуляція лювію сьомої н дз пл в- } \\
\text { ної тер си (рівень р сної), імовірне } \\
\text { розчленув ння цієї тер си т вироблен- } \\
\text { ня ерозійного уступу до шостої н дз п- } \\
\text { л вної тер си (рівня оєвої) }\end{array}$ \\
\hline
\end{tabular}

лий лубненський ч с (викопний грунт у розрізі гвіздя і русловий гр війно-г лечниковий м тері л тер си у личі) і з вершився цей п леогеогр фічний ет п холодним тілігульським ч сом (лесовий горизонт у розрізі гвіздя і перигляці льний лювій у розрізі лич).

пропонов ні схеми п леогеогр фічних подій верхньопліоцен-нижньоплейстоценового ет пу формув ння долини ністр $\epsilon$, н н шу думку, цінними з погляду нового $б$ чення історії геоморфологічного розвитку ередк рп ття, оділля. Дн к очевидно, що пост влен проблем ще н дзвич йно д лек від ост точного вирішення.

1. огуцький . ., цищин . . кологічний ст н геоморфосфери // кологія лицького р йону. в но- р нківськ: ов оря, 2004. . 29-31.

2. огуцький . ., цишин . . етвертинні відкл ди // кологія лицького р йону. в нор нківськ: ов оря, 2004. . 26-27.

3. еклич . с сновні ет пи розвитку річкових долин // еоморфологія річкових долин кр їни. .: ук. думк , 1965. . 7-26.

4. еклич . . т пы обр зов ния позднек йнозойских речных долин кр ины // ечные системы и мелиор ция. овосибирск: зд-во , 1977. . 1. . 23-26.

5. еклич . . леоэт пность стр тотипы почвенных форм ций верхнего к йнозоя. $\quad . \quad$ ук. думк , 1982. $202 \mathrm{c}$.

6. офштейн . . еотектонік і морфогенез ерхнього ридністров'я. .: ид-во 1962. $131 \mathrm{c}$.

7. офштейн . . еотектоник з п дной олыно- одолии..$\therefore$ ук. думк, 1979.159 с. 
8. емедюк . . . ро генезис лесових порід ередк рп ття // оп. .200-204.

9. емедюк . . етвертинні відкл ди // рирод в но- р нківської обл сті. ьвів: ид-во ьвів. ун-ту, 1973. . 25-31.

10. емедюк . . ревние поверхности выр внив ния кр инских рп т // Studia Geomorphologica carpatho-balcanica. 1983. Vol. 16. . . 3-14.

11. одонов . . етвертичный период редней зии: тр тигр фия, корреляция, п леогеогр фия. $\quad \therefore \quad$,2002. $250 \mathrm{c}$.

12. $р$ вчук . . еоморфологія ередк рп ття. ьвів: ерк тор, 1999. 188 с.

13. з ренко. . н нов . ., ерняков . . тчёт в но- р нковской геологосъёмочной п ртии з 1970-1973 рр. иев, 1973. н. 3. 400 с.

14. 3 ренко . ., нков . ., ерняков . . еологичек я к рт м сшт $6 \quad 1: 50000$. исты: -35-98- ( лич), -35-110- ( в но- р нковск), -35-110- ( исмениц ), -35110- ( тыня). иев, 1973.

15. олянський . одільські етюди. ер си, леси і морфологія лицького оділля н д ністром // б. тем.-природопис.-лік р. секції . 1929. . 20.191 с.

16. $и с b$. . еоморфологія . ьвів: ид-во ьвів. ун-ту, 1962. 223 с.

17 цишин . . еоморфологічн будов долини ністр у меж х ередк рп ття: втореф. дис... к нд. геогр. н ук. ьвів, 2001. 18 с.

18. цишин . ореляція тер с ністр у меж х ередк рп ття з основними стр тигр фічними горизонт ми лесово-грунтової серії олино- оділля // уч сні проблеми і тенденції розвитку геогр фічної н уки: тері ли міжн р. конф. до 120-річчя геогр фії у ьвів. ун-ті. 24-26 вересня 2003 р. ьвів: ім. . р нк , 2003. . 285-287.

19. цищин ., огуцький ., лотніков . т пи формув ння т геоморфологічн будов долини p. тривігор у меж х ередк рп ття // існ. ьвів. ун-ту. ер. геогр. 2008 . ип. 35. . 348-360.

20. Lessy i paleolit Naddniestrza halickiego (Ukraina) / Pod red. T. Madeyskiej // Studia geologica Polonica. 2002. Vol. 119. C. 3. - 391 p.

\section{THE PRINCIPAL STAGES HIGH PLIOCENE AND LOW PLEISTOCENE MORPHO AND LITHOGENESIS OF THE DNIESTER BASIN IN THE HALICIAN DNIESTER REGION}

\section{A. Jacyshyn}

Ivan Franko National University of Lviv, . Doroshenko St., 41, UA - 79000 Lviv, Ukraine

The principal stages of high Pliocene and low Pleistocene history of the Dniester basin development in Halicia and Ivano-Frankivsk region on the basis of the detailed morphological, morphometric analysis of the Dniester terraces as well as its Carpathian streams and the analysis of cut terraces. The fundamental geomorphological research of Loyeva, Krasna rivers levels has been done and some determined provisions about their structure, development and time of formation were defined. Paleogeographic events are related with the stages of isotopic-oxygen scale, paleomagnetic rappers, stratigraphic horizons of loess and soil series of the Halician Dniester region.

Key words: level of Krasna river, level of Loyeva river, terrace, isotopic-oxygen stage, tectonic raising, erosive cutting, alluvium accumulation. 


\section{• цИШин}

ввовский н цион льный университет имени в н ул. . орошенко, 41, г. ввов, 79000, кр ин

основ нии дет льного морфологического, морфометрического н лиз терр с нестр , его к рп тских приток, н лизе р зрезов терр с реконструиров но гл вные эт пы верхнеплиоцен-нижнеплейстоценовой истории р звития долины нестр в р йоне лич, в но- $p$ нковск . ыполнены дет льные геоморфологические исследов ния уровней оевой, р сной и уточнены некоторые уже широко известные положения об их строении, р спростр нении, времени формиров ния. леогеогр фические события скоррелиров ны со ст диями изотопно-кислородной шк лы, п леом гнитными репер ми, стр тигр фическими горизонт ми лёссово-почвенной серии лицкого риднестровья.

лючевые слов : уровень р сной, уровень оевой, терр с , изотопно-кислородн я ст дия, тектонические поднятия, эрозионное врез ние, ккумуляция ллювия.

т ття н дійшл до редколегії 08.05.2009 рийнят до друку 20.09.2009 